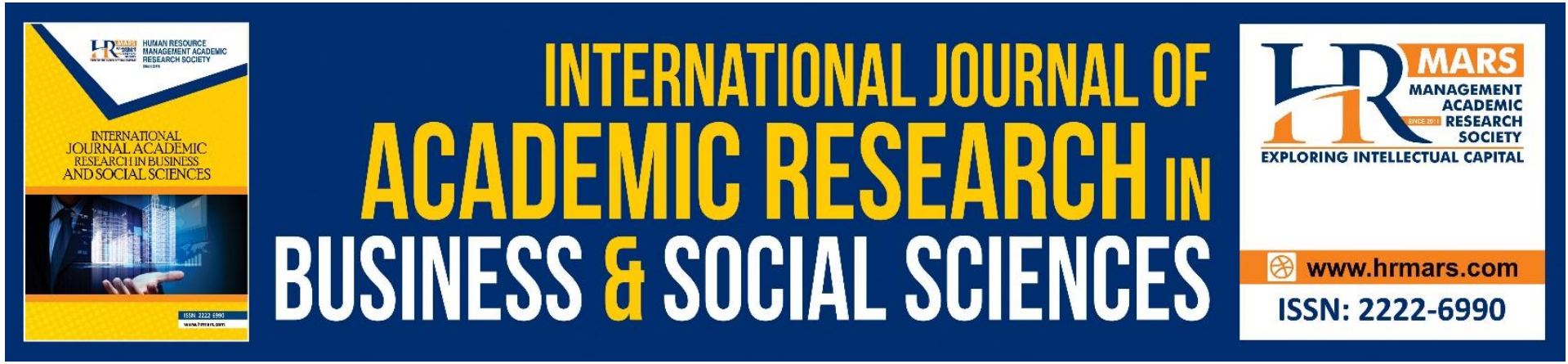

\title{
Empowering A Career Transition Program Among Disabled Students: The Educators' Experience
}

\section{Ardzulyna Anal, Noor Aini Ahmad \& Mohd Khaidir Che Hassan}

To Link this Article: http://dx.doi.org/10.6007/IJARBSS/v11-i7/10515

DOI:10.6007/IJARBSS/v11-i7/10515

Received: 17 May 2021, Revised: 20 June 2021, Accepted: 07 June 2021

Published Online: 26 July 2021

In-Text Citation: (Anal et al., 2021)

To Cite this Article: Anal, A., Ahmad, N. A., \& Hassan, M. K. C. (2021). Empowering A Career Transition Program Among Disabled Students: The Educators' Experience. International Journal of Academic Research in Business and Social Sciences, 11(7), 588-594.

\section{Copyright: (c) 2021 The Author(s)}

Published by Human Resource Management Academic Research Society (www.hrmars.com)

This article is published under the Creative Commons Attribution (CC BY 4.0) license. Anyone may reproduce, distribute, translate and create derivative works of this article (for both commercial and non-commercial purposes), subject to full attribution to the original publication and authors. The full terms of this license may be seen at: http://creativecommons.org/licences/by/4.0/legalcode

\section{Vol. 11, No. 7, 2021, Pg. 588 - 594}

Full Terms \& Conditions of access and use can be found at http://hrmars.com/index.php/pages/detail/publication-ethics 


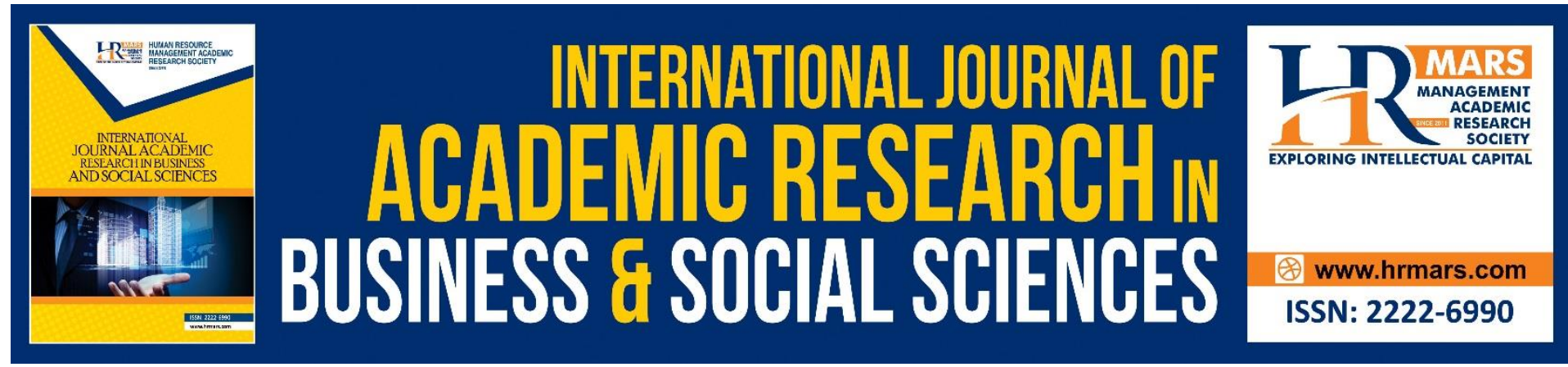

\title{
Empowering A Career Transition Program Among Disabled Students: The Educators' Experience
}

\author{
Ardzulyna Anal ${ }^{1}$, Noor Aini Ahmad ${ }^{1} \&$ Mohd Khaidir Che \\ Hassan $^{2}$
}

${ }^{1}$ Special Education Department, Faculty of Human Development, Universiti Pendidikan Sultan Idris, Malaysia, ${ }^{2}$ Kolej Komuniti Selayang (Selayang Community College)

\begin{abstract}
The development in today's education has made the technical and vocational education and training (TVET) a necessity, especially in generating skillful and trained workers who may enhance the country's international industrial competitiveness. Numerous institutions have gained recognition from the Department of Skills Development as recognized centers to provide skills trainings that offer Malaysian Skill Certificate for courses as listed by National Occupational Skills Standard. These institutions become a platform for individuals from various backgrounds (including the disabled) to prepare themselves for their career advancement. To those disabled individuals, having a career is essential as to ensure their own life survival, besides meeting their life aims. Therefore, through the Malaysian Plan of Action for People with Disabilities 2016-2022, the effort of Social Welfare Department Malaysia to empower the career transition program in educational institutions, particularly in providing skills training vividly portrays the important role of educators in guiding the disabled to create their career path.
\end{abstract}

Keywords: Empowering, Career Transition Programme, Disabled Students, Educators

\section{Introduction}

According to the Persons with Disabilities Act (2008), people with disabilities refer to those individuals with long-term physical, mental, intellectual or sensory disabilities who, when interacting with various barriers, can restrict their full and effective participation in society. To be more specific, these disabled people have been categorized to hearing disability, visional disability, speech disability, physical disabilities, mental disability, multiple disabilities and learning disabilities (Social Welfare Department Malaysia, 2016). These individuals with disabilities include students, of whom, according to Education Act (1996), refers to those who are given education or training in any educational institution regardless of their age.

Having discussed career related matters, disabled students need a special program of which it may help provide an early preparation platform for them. Such preparation is in terms of the career related knowledge, skills and experience. TVET based education is seen as a good approach in instilling career awareness among the disabled as it aims at optimizing their involvement in the society and ensuring that these group of people is not left behind (Suk 
et.al., 2020). Depending on their own abilities, advancing a career is vital among the disabled as it serves as an avenue for them to contribute to the country's productivity. Hence, a career transition program is believed to be designed and implemented more effectively as it provides knowledge and skill based curriculum which may help create a career path for the disabled students.

Discussing its importance, Alias (2014) states that career transition benefits students not only in terms of preparing them for the transition process yet in allowing them to gain real world working experiences (based on the students' potential as recognized by educators). If any career transition program is implemented with the collaboration with various agencies and industries, the disabled students who have joined career transition program since school may have the potential to continue their studies in higher learning institutions thus would have better opportunities to get a job.

Therefore, several aspects need to be taken into consideration when implementing career transition programs. These include integrating various vocational skills in special education curriculum, involving employers in developing the career transition programs, creating collaboration with vocational training institutes in preparing spaces for alternative education and cooperating with both private sectors and non-government organizations as proposed by Malaysia Education Development Blueprint (2013- 2025). The need of career transition is in line with the transformation of TVET in which it prepares equal opportunities to all students regardless of their background. Everybody, including those who do not excel academically, has the access to education where individuals' potential is to be grown in mastering certain skills so everybody is able to compete healthily in today's career industry.

\section{Research Methodology}

This research is a case study which employed a qualitative approach. The researcher conducted semi-structured interviews to collect data for this research. Using the purposive sampling technique, two educators with five years of experience in handling career transition program with the disabled were selected to be interviewed. The interview was conducted aiming at exploring the educators' experiences and opinions in the effort of highlighting the best practices to empower the career transition program among the disabled.

\section{Research Findings}

Results show that there are five main elements that need to be paid attention to as a preparation in empowering the career transition program among the disabled: (i) Readiness in Implementing Learning and Teaching Pedagogy, (ii) Readiness in Implementing Students' Skills Level Identification, (iii) Readiness in Creating Collaboration with many Parties, (iv) Readiness in Implementing Career Based Curriculum Approach, (v) Readiness in Instilling Working Experiences.

\section{(i) Readiness in Implementing Learning and Teaching Pedagogy}

Educators' competence in implementing effective strategies for the teaching and learning process is vital in handling the career transition program. Researchers like Luckner, Sebald and Ann (2013), together with Morningstar and Benitez (2013) highly emphasize that an educator must have good skill background and competency in delivering effective teaching 
and learning. According to Respondent 1, among the approaches used in the teaching and learning include practising scaffolding technique, mastery learning, role model, demonstration, delivering lessons using visual technology, visits as well as learning that emphasizes individual differences. The differences in this context refer to the unique abilities and disabilities of each individual student that require careful attention by the educators.

\section{(ii) Readiness in Implementing Students' Skills Level Identification}

In implementing career transition program among the disabled, Warner (2020) is in the opinion that educators have to be able to identify certain skills related to positive selfdevelopment especially among those with communication disability. Respondent 1 shared, besides identifying main skills to be acquired by individual student, educators too need to identify factors that affect students' development in various domains. Educators are also anticipated to understand the process that may help increase the students' functionality so they may adapt well in the transition from educational institutions to the career world. For Respondent 2, the element of life management must be polished or enhanced by educators who conduct the career transition program. The element includes the skills of living on one's own feet, self image, communication, social development, sports and recreation, career related skills, academic, mobility, self advocacy, entrepreneurship, employment, community involvement and self esteem. Hence, different forms of evaluation need to be done by educators to measure necessary skills required by each individual student.

\section{(iii) Readiness in Creating Collaboration with many Parties}

Zhong (2018) propagates that collaboration in the context of career development plays an important role in strategizing an effective transition program. This is in line with Haber et al., (2016) who believe that creating collaboration should be among the main elements to consider in career transition program. Findings from Respondent 1 indicate that collaboration from family is highly needed in career placement during the industrial training. This is parallel to Papay et al (2015) who state that getting family's cooperation is the most important aspect to be taken into consideration. To Respondent 2, educators ought to be ready to collaborate with certain agencies including industrial parties, government bodies and non-government organizations. This is to ensure the disabled students' marketability after they have completed their studies, besides knowledge and skill enhancement. Not only that, Respondent 1 also stated that collaboration with the industrial parties provides certain benefits especially in terms of instilling awareness among employers to increase the acceptance of the disabled in the working industries.

\section{(iv) Readiness in Implementing Career Based Curriculum Approach}

Discussing the skills related to career advancement, the researcher found out that the practical career based teaching and learning is suitable to be implemented with the disabled. They may be able to master and apply the knowledge and skills learnt in a real world setting (Gilmour, 2019). Respondent 1 indicated that implementing career based curriculum is appropriate for the disabled students and it allows students to get jobs within a short period of time after they have completed their studies. Agreeing to Respondent 1, Respondent 2 stated that students are well accepted in the working industries especially if the students are well trained in terms of basic IT skills, job seeking skills, job application skills and interview skills. Hence, these career related skills are necessary in designing and delivering career based curriculum. 
This finding is in line with Newman et al (2016) who states that career transition program must serve as a medium for the disabled students to acquire and master certain skills so they are eligible to be accepted in the industrial world. Career based curriculum which emphasize on practical training must be made as guidance for any career transition program. Therefore, educators must prepare themselves in terms of eligibility, skills, experience and values in order to ensure good teaching and learning outcomes (Haber et al., 2016), besides preparing the students with career based curriculum elements.

\section{(v) Readiness in Instilling Working Experiences}

William (2013) indicates that the use of physical and mental energies through any learning process which leads to certain product-based outcomes is seen to be more meaningful as it provides direct experiential learning. This approach is an effort to help the disabled get better job opportunities in the future (Punch, 2016). In this research, the research discovered that working experience instilled in students through industrial training has left positive impacts in students' development, especially in preparing them for a real-world career. According to Respondent 1, educators must be in the know of the actual ability of each individual student. This includes the students' skills, interest, self confidence and ability to adapt in actual career challenges. For instance, direct practical experiences gained through entrepreneurship courses prepare students with knowledge and experience to venture into certain business fields and face any upcoming challenges. Therefore, it is important for educators themselves to equip themselves with such skills. This allows the educators to transfer and share the knowledge and skills to the students more effectively, thus prepares the students to improve themselves theoretically and practically.

From the perspective of Respondent 2, working experiences enable students to have high level of self reliance and practice positive values. Hence, educators must have strategies in ensuring students' marketability right after they have completed their studies. Respondent 1 added, students must be prepared with skills like technology use, specific career related skills, in depth knowledge about industrial career situation and readiness to cope with career related challenges. Hence, proper planning and preparation pertaining to the working ambience should be exposed to disabled students so they are able to prepare themselves and to be more confident in adapting themselves in the real world career (Woodar, 2018).

\section{Conclusion}

Throughout this research, it is discovered that educators' competence is crucial in the career transition program, especially in preparing disabled students with effective transition practices. Transformation and development of various knowledge disciplines require educators to be ready to make any shifts so the teaching and learning can be aligned with the world $4^{\text {th }}$ industrial revolution which surely leaves impacts on the working sector. This readiness is necessary so educators in the world of education may face any challenges that come their way in the effort of equipping disabled students with better opportunities in schools, working arena and in life generally. This justifies the need of empowering the career transition program, other than to produce good human capital who can contribute to human resource optimization as required in today's industrial world. 


\section{Corresponding Author}

Ardzulyna Anal

Faculty of Human Development, Universiti Pendidikan Sultan Idris, Malaysia

Email: ardzulyna@fpm.upsi.edu.my

\section{References}

Alias, A. (2014). Transition program: The challenges faced by special needs students in gaining work experience. International Education Studies, 7(13), 192-196.

Education Act. (1996). Laws of Malaysia Act 550. Section 55: Malaysia.

Gilmour, A. F. (2019). Teacher certification area and the academic outcomes of students with learning disabilities or emotional/behavioral disorders. The Journal of Special Education. 54(1). 40-50.

Haber, M. G., Mazzotti, V. L., Mustian, D. L., Rowe, D. A., Bartholomew, A. L., Test, D. W., \& Fowler, C. H. (2016). What works, when, for whom, and with whom a meta-analytic review of predictors of postsecondary success for students with disabilities. Review of Educational Research, 86(1), 123-162.

Luckner, J. L., Sebald, \& Ann, M. (2013). Promoting self-determination of students who are deaf or hard of hearing. American Annals of the Deaf. 158(3), 377 -386.

Ministry of Education Malaysian. (2013). The Malaysia education blueprint 2013-2025 (preschool to post-secondary education) 2013-2015. Putrajaya: Malaysia.

Social Welfare Department Malaysia. (2016). Malaysian plan of action for people with disabilities 2016-2022. Putrajaya: Ministry of Women, Family and Community Development, Malaysia.

Morningstar, M. E., \& Benitez, D. (2013). Teacher training matters: The results of a multi-state survey of secondary special educators regarding transition from school to adulthood. Teacher Education and Special Education, 36 (1), 51-64.

Newman, L. A., Madaus, J. W., \& Javitz, H. S. (2016). Effect of transition planning on postsecondary support receipt by students with disabilities. Exceptional Children, 82(4) 497-514.

Papay, C., Unger, D., Williams-Diehm, K., \& Mitchell, V. (2015). Begin with the end in mind: Infusing transition planning and instruction into elementary classrooms. Teaching Exceptional Children, 47(8), 310-318.

Persons with Disabilities Act. (2008). Laws of Malaysia Act 685.

Punch, R. (2016). Employment and adults who are deaf or hard of hearing: current status and experiences of barriers, accommodations, and stress in the workplace. American Annals of the Deaf, 161(3), 384-397.

Suk, A. L., Sinclair, T. E., Osmani, K. J., \& William-Diehm, K. (2020). Transition planning: keeping cultural competence in mind. Career Development \& Transition for Exceptional Individuals, 43(2), 22-127.

Warner, L. H. (2020). Developing interpersonal skills of evaluators: a service-learning approach. American Journal of Evaluation, 35, 579-593.

William, L. H. (2013). Exceptional Children An Introduction To Special Education. (10th ed.). Boston: Pearson.

Woodar, E. W. (2018). An exploratory qualitative study of soft skill development through individual internship experiences in a workplace setting (PhD Dissertation). The George Washington University. 
Zhong, X. (2018). Information technologies, policy leverage, and the entrepreneurial spirit: building cross-sectoral collaboration for disability employment in China. Journal of Asian Public Policy, 3(2), 208-226. 